\title{
UTICAJ ZADATAKA SA OGRANIČENJIMA NA KRETANJE NAPADAČA U SEGMENTU IGRE 1 NA 1 U TRENINGU FUDBALERA
}

\author{
Filipe Clemente $^{1}$, Micael Couceiro ${ }^{2}$, Fernando Martins ${ }^{3,4}$, Gonçalo Dias ${ }^{1}$ i Rui Mendes ${ }^{4,5}$

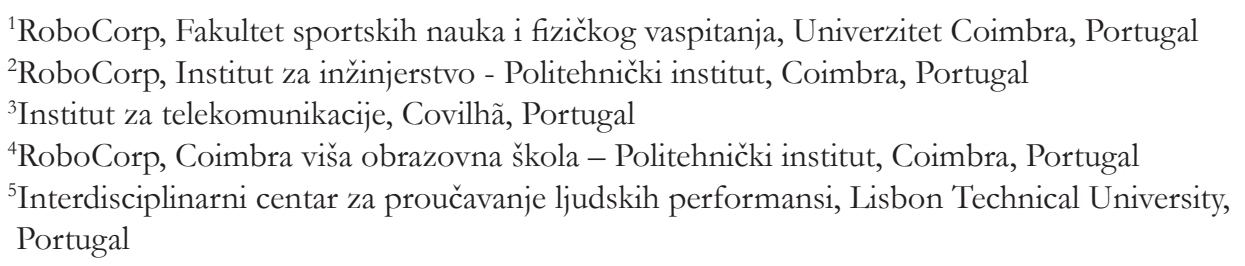

\section{SAŽETAK}

Vježbe koje najčešće koriste treneri u treningu sa svojim igračima su zadaci sa ograničenjima (Araújo, 2006; Newel, 1986). Tema ovog istraživanja je analiza korištenja prostora i kretanja napadača u treningu, kada su im dati određeni zadaci sa ograničenjima u napadačkoj akciji 1 na 1 . Ovim istraživanjem je analizirano 11 fudbalera $(17,91 \pm 1,04$ godina) sa igračkim iskustvom 8,60 $\pm 1,52$ godine. Toplotne mape predstavljaju razlike u korištenoj površini terena u različitim uslovima treninga. Analiza varijanse trajanja napadačkog pokušaja takođe je predstavila statističke razlike u različitim uslovima treninga $\left(F_{(2,27)}=30,776 ; p=0,01\right)$. Rezultati pokazuju da se u rizičnim situacijama napadač opredjeljuje za prostorno-vremensku simetriju. S druge strane, kada dobije upustva da zadržati loptu, za razliku od rizik ograničenja, dolazilo je do lateralizacije akcija, povećanja varijabilnosti i disperzije kretanja napadača. Ovo istraživanje je pokazalo važnost korištenja zadataka sa ograničenjem.

Ključne riječi: vježbe sa ograničenjem, uputstva, fudbal, korištenje prostora, toplotne mape. \section{UVOD}

Zadaci sa ograničenjima mogu uticati na ponašanje sportista na različite načine (Davids i Araújo, 2005; Davids, Button i Bennett, 2008; Newell, 1986). Pristup zasnovan na ograničenjima (ABC pristup) odgovara stvaranju obrazaca ponašanja u sportu (Araújo, Davids, Bennett, Button i Chapman, 2004; Davids i saradnici, 2008), uzimajući u obzir akcije izvođača, karakteristike zadatka i prostora u kojem se zadatak izvršava (Araújo, 2006).

Ograničenja mogu da naprave restrikciju ili omoguće raznovrsno ponašanje koje sportista može da usvoji (Davids i saradnici, 2008). Konkretno, zadaci sa ograničenjem mogu pomoći igračima da usmjere svoju pažnju na specifične informacije. Dakle, to su pravila koja ograničavaju prostorne i vremenske obrazce u dinamici kretanja tokom aktivnosti koja se posmatra (Handford, Davids, Bennett i Button, 1997). Treba napomenuti da kod pojedinaca koji usvajaju vještine treba uzeti u obzir upravljanje značajnim ograničenjima kako bi se postigli željeni odgovori (Clemente i Mendes, 2011a). Na primjer, trener može nametnuti ograničavajuće pravilo koje zahtijeva takve kretnje koje dozvoljavaju samo šut izvan kaznenog prostora (Handford i saradnici 1997). Shodno tome, trener može da koristi ograničenja da poboljša kvalitet vježbe, usmjeravajući pažnju igrača na informacije koje smatra važnim (Clemente, Couceiro, Martins i Mendes, 2012a). Trener često koristi zadatak sa ograničenjima za provođenje sadržaja treninga (Davids i Araújo, 2005). U tom smislu, jedna od glavnih funkcija sportskih trenera je da identifikuju i da koriste najvažnija ograničenja koja unapređuju samoorganizovanje ponašanja motoričkog sistema u određenoj igri (Vilar, Castelo i Araújo, 2010). Sa ove tačke gledišta, zadatak sa ograničenjima obuhvata pojednostavljena pravila igre, broj igrača ili prostor za vježbanje (Figueira \& Greco, 2008), sa naglaskom na vještinu igrača koji treniraju i specifične ciljeve zadatka (Clemente i Mendes, 2011a; Clemente i saradnici, 2012a). 
Pored toga, podjela igre u podsisteme, faze ili pojedinačne akcije omogućava analizu igre iz ugla intraveza $i$ interveza između igrača (McGarry, Anderson, Wallace, Hughes i Franks, 2002). Dakle, moguće je definisati odnose između igrača i timova na tri nivoa: 1) unutrašnja koordinacija, 2) unutrašnja i međukoordinacija između igrača, i 3) unutrašnja i međukoordinacija tima (Travassos, Araújo, Correia i Esteves, 2010).

Noviji radovi u timskim sportovima proučavali su segmente igre 1 na 1 (tij., analizu unutrašnje koordinacije), ukazujući na važnost upravljanja zadatacima sa ograničenjima (Araújo, 2006, Duarte i saradnici, 2010b;. Passos i saradnici, 2008.; Passos, Lopes i Milho, 2008). Ograničenja kao što su veličina terena za igru, broj igrača ili upustva dobijena od strane trenera mogu biti od koristi kako bi se zadatak prilagodio specifičnostima igrača.

Dakle, upustva koja daje trener su jedan od zadataka sa ograničenjem koji utiču na ponašanje igrača (Clemente i Mendes, 2011b). To potvrđuju neke novije studije (Araújo, 2006; Clemente i Mendes, 2011b; Clemente, Mendes i Soler, 2011) ukazujući na važnost upravljanja upustvima koje daje trener sa ciljem da igrač ima bolju percepciju zadatka, a što dovodi do značajnih promjena u oba procesa i stvara raznovrsnost. Drugim riječima, u tom kontekstu uloga povratne informacije ili upustvo može da se posmatra kao način da se prošire informacije o okolini kako bi doveli igrače u situaciju da moraju da pronalaze sve bolja rješenja koja zadovoljavaju ograničenja koja je trener tražio (Araújo, 2006; Davids i Araújo, 2005).

Araújovo (2006) istraživanje igre 1 na 1 u košarci pokazalo je da različiti zadaci pokreću igrače da donose različite odluke. U stvari, prema autoru, situacije u kojima su uputstva dovodila do rizika rješenja, češće su primjećivana u prostorno-vremenskoj simetriji.

Kod Clemente i Mendes (2011b) i Clemente i saradnika (2011) izučavanje segmenta igre $1 \mathrm{na} 1 \mathrm{kod}$ mladih fudbalera pokazalo je da napadač (npr. igrač koji posjeduje loptu) izvodi akciju pod uticajem tri vrste zadataka sa ograničenjem (rizik, neutralni i konzervativni). Naglašeno je da u sva tri zadatka sa ograničenjem, glavni cilj je bio da se uspješno završi napada, tj. da se postigne gol.

$\mathrm{KrOz}$ analizu promjenljive varijable (tj. analizu kretanja) kod fudbalera mladih od 12 godina (Clemente i Mendes, 2011b), bilo je moguće provjeriti statistički značajne razlike između ograničenja vezanih za upustva trenera, ukupnog vremena potrebnog za jedan napad, korištenja obje noge, učestalost nadigravanja odbrane, izgubljene lopte i šuteve na gol.

Ukratko, pregledna istraživanja o zadacima sa ograničenjema (npr. rizikovati ili zadržati loptu) upućuju na to da je moguće zaključiti da postoje značajne razlike između rizik zadataka i konzervativnih zadataka što nas dovodi do zaključka da trener može diktirati nastup igrača koristeći se zadacima sa ograničenjema, a što rezultira različitim vrstama akcija (Araújo, 2006; Clemente i Mendes, 2011b; Clemente i saradnici, 2011).

Međutim, istraživanja o zadacima sa ograničenjima samo preuzetim iz notacione analize zenemaruju kinematičke varijable, kao i kretanja igrača u različito zadanim uslovima. U stvari, ako se vrijeme kod konzervativnih zadataka produžava, moguće je da će igrač napraviti različite kretnje da bi izbjegao protivnika $\mathrm{i}$, istovremeno, zadržati loptu da bi napao u pravom trenutku.

\section{SLIKA 1}

\section{Slika koja ilustruje dimenఇije protora koristenog tokom istraživanja.}

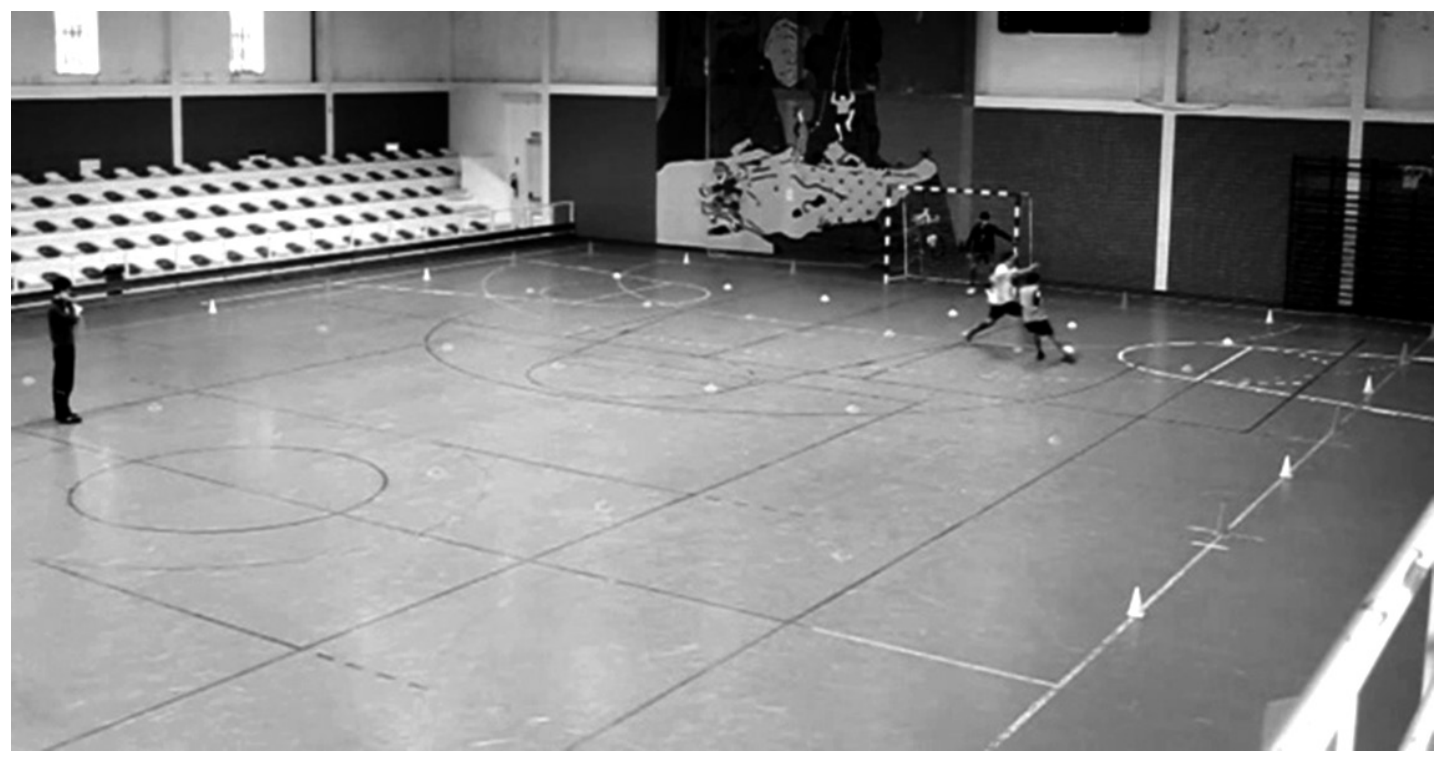


Stoga je glavni cilj ovog istraživanja bio da se analizira prostorno kretnje fudbalera u segmentu igre 1 na 1 sa golmanom. Osim toga, namjera je bila analizirati putanje kretanja igrača na terenu kada je pod utjecajem zadatka sa ograničenjem tako što su prostorne kretnje sportista registrovane toplotnim mapama.

\section{METODE}

\section{Ispitanici}

Ovo istraživanje analizira 11 fudbalera muškog pola iz federalne ekipe okruga Coimbra (Portugal), starosti $17,91 \pm 1,04$ godina i sa $8,60 \pm 1,52$ godina igračkog iskustva.

\section{Dizajn eksperimenta}

Segment fudbalske igre 1 na 1 sa golmanom sproveden je u prostoru 19,6 metara (m) širine i 18 $\mathrm{m}$ dužine sa markerima na krajevima polja (Slika 1).

$\mathrm{Na}$ početku svakog pokušaja, odbrambeni igrač se postavlja na udaljenosti $6 \mathrm{~m}$ od napadača, koji se postavljao na sredini terena, na rastojanju $18 \mathrm{~m}$ od gola. Pored toga, golman ne smije napuštati gol liniju.

Zadatak se sastojao u realizaciji pokušaja napada (tj. postizanja gola) od strane napadača u situaciji 1 na 1 sa golmanom.

\section{Uslovi zadatka}

Ispitanici su uzajamno djelovali u igri 1 na 1 sa golmanom. Svaki ispitanik izvodio je vježbu tako što je dobijao tri vrste zadataka sa ograničenjem: 1) konzervativno, 2) rizik i3) neutralno. Kod konzervativnih zadataka, napadač je dobio informaciju da njegov tim vodi, tako da je on napadao samo kad je imao priliku za to. Kod rizik zadataka, napadač je bio informisan da utakmica ubrzo završava i da njegova ekipa gubi što je rezultiralo rizik ponašanjem. Konačno, kod neutralnih zadataka, dobijala se informacija da napadač treba da pokuša da postigne gol. Kod svih zadataka cilj je bio postići gol.

U svakom od ova tri slučaja (konzervativnom, rizik i neutralnom) izvedeno je po 10 ponavljanja. Prije istraživanja, svi ispitanici su imali po jedan napadački pokušaj da bi shvatili šta se od njih traži.

U svakom od tri slučaja, napadaču je rečeno da test završi šutem nogom (tj. postigne gol). S druge strane, odbranbenom igraču je saopšteno da treba da spriječiti postizanje gola. Prije početka svakog ispitivanja, dati su zadaci sa ograničenjem (konzervativani, rizik ili neutralni) i napadač bi započinjao sa izvođenjem napada. Svi pokušaji izvođeni su u skladu zvaničnim fudbalskim pravilima za ovu starosnu grupu.

\section{Procedure}

Napadačke akcije registrovane su digitalnim SLR fotoaparatom (Canon EOS 500D) sa kapacitetom obrade slika od $30 \mathrm{~Hz}$ (tj. 30 slika u sekundi). Kamera je postavljena na 4,53 m iznad tla, u sagitalnoj ravni, kako bi zabilježila cijeli zadatak (Slika 1). Korištene su zvanične lopte za ovu uzrasnu grupu igrača. Upotrebljeni su narandžasti i žuti prsluk za napadača i odbrambenog igrača. Kretanje igrača je analizirano uz pomoć MATLAB-a.

Nakon snimanja napadačkog pokušaja, fizički prostor je kalibrisan uz pomoć direktne linearne transformacije (DLT), koja se odnosi na poziciju objekta (npr. igrača) u metričkom prostoru sa odgovarajućim objektom na slici (Duarte i saradnici, 2010a).

Mapiranje omogućava konstruisanje histograma frekvencija na osnovu prostorne distribucije napadača, što rezultira grafičkim prikazom toplotnih mapa.

U tu svrhu, cijeli prizor bio je podijeljen na segmente $20 \times 20 \mathrm{~cm}$ što rezultira podjelom manjom od $1 \mathrm{~m}^{2}$, koje određeni igrači češće zauzimaju u jednom od tri različita slučaja na treningu. Slika 2 ilustruje primjer histograma.

Kako bi podržali analizu zauzetih zona proveli smo dizajn toplotnih mapa. Ove topline mape sastoje se iz grafičkog predstavljanja podataka u kojima su frekvencije vrijednosti koje su dobijene na osnovu prostorne distribucije u histogramima predstavljene u dvodimenzionalnoj tebeli s različitim bojama. Tamnije boje predstavljaju veću frekvenciju zauzimanja određenog prostora na terenu.

Pored toga, za analizu distanci kretanja, takođe smo napravili statističku analizu vremena potrebnog napadaču da završi akciju u svakoj od tri situacije. Stoga smo koristili jednostruku ANOVA da se utvrde statistički značajne razlike između fudbalera, u svakom od tri slučaja na terenu. Pretpostavka o normalnosti distribucije jednostruke ANOVA u svakom od tri slučaja na terenu (konzervativnom, neutralnom i rizik) ispitivana je uz pomoću Kolmogorov-Smirnov testa sa Lilleforsovom korekcijom. Utvrđeno je da distribucija za zavisnu varijablu nije normalna. Iako distribucija nije normalna, jer je $n=30$, koristeći centralnu graničnu teoremu (Maroko i Bispo, 2003; Pedrosa i Gama, 2004) postavili smo pretpostavku o normalnosti (Akritas i Papadatos, 2004). Analiza homogenosti je sprovedena uz pomoću Leveneovog testa. Utvrđeno je da ne postoji uniformnost treninga u odnosu na predhodno navedene uslove. Međutim, uprkos nedostatku homogenosti, $F$ test (ANOVA) je i dalje dobar i pored kršenja homogenosti kada je broj 
zapažanja u svakoj grupi jednak ili približno jednak (Pestana i Gageiro, 2008, Maroko, 2010; Vicent, 1999), a što je ovdje slučaj. Kao i kod pretpostavki o normalnosti, kršenje ove pretpostavke nije značajno promijenilo F vrijednost (Vicent, 1999). Osim toga, koristili smo Games-Howell Post hoc test (Laureano, 2011). Ova analiza je provedena uz pomoću IBM SPSS programa (verzija 19) na nivou značajnosti od $5 \%$.

\section{REZULTATI}

Korišteni su histogrami kako bi kvantifikovali kretanje igrača u prostoru. Odatle i individualne toplotne mape (Slika 3), koje omogućavaju da se zapaze promjene u kretanju napadača, a koje su posljedica kretanja po različitim zadacima sa ograničenjem (konzervativni, rizik i neutralni).

Utvrdili smo smanjenje širenja prostora koje pokriva napadač kod neutralnih i rizik zadataka sa ograničenjem, evidentnu pojavu vertikalnih zona driblinga sa loptom (npr. napadač centralizuje svoje djelovanje i kretanje prema cilju). S druge strane, kod konzervativnih zadataka sa ograničenjem, kretanje je lateralizovano (tj. veće zauzimanje zona sa strane), što predstavlja veći prostor disperzije.

Slika 4. ilustruje tendenciju igrača da idu u lijevu stranu u prostoru za vježbanje. Međutim, uprkos ovom trendu postoje i postepeni vertikalni pravci igrača kod neutralnih i rizik zadataka sa ograničenjima. Naglašavamo da su kretanja u skladu sa ciljevima igrača, kada se ispunjavaju neutralni i rizik zadaci sa ograničenjima.

Jednostruka ANOVA, kada je u pitanju vrijeme pokušaja napada, pokazala je statističke razlike između

\section{SLIKA 2}

Ilustracija slike histograma koja predstavlja najzauzitije dijelove terena od strane igrača u jednom od tri slučaja na treningu.

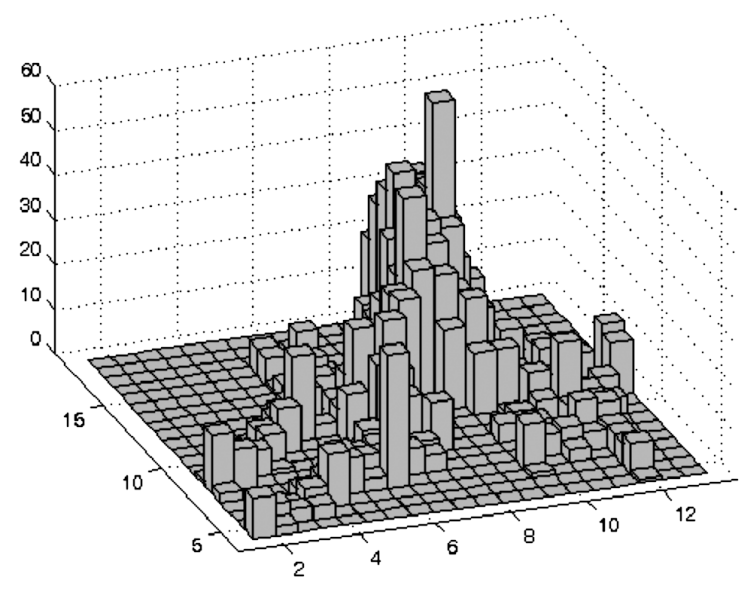

različitih situacija u treningu $\left(F_{(2,327)}=30,776 ; p=\right.$ 0,01).

Konkretno, post hoc test pokazao je razlike izmedu rizik i konzervativnih ograničenja $(p=0,01)$ i rizik i neutralnih ograničenja $(p=0,01)$. Pod utjecajem rizik ograničenja igračima je trebalo manje vremena da završe napada u odnosu na druga ograničenja. Isto tako, konzervativna ograničenja pokazuju statistički značajne razlike u odnosu na neutralna $(p=0,035), \mathrm{i}$ traže više vremena da se napada završi.

\section{DISKUSIJA}

Cilj ovog istraživanja bio je da se analizira uticaj zadataka sa ograničenjima na kretanje napadača. Pored toga, izvršena je statistička analiza kako bi se utvrdila razlika u vremenu potrebnom igračima za završetak svakog napada kada imaju različito postavljenje zadatke.
Rezultati pokazuju da su igrači, kada su dobili zadatke sa rizik ograničenjima, koristili direktne akcije po dubini (tj. dribling loptom prema golu), a smanjili su varijabilnost kretanja tako što si izbjegavali dijelove terena uz bočne linije. Slični rezultati mogu se zapaziti kod Araujo (2006), gdje su se košarkaši s loptom kretali s manje varijabiliteta preko terena kako bi završili napad za što je moguće kraće vrijeme. U rizik ograničenju, igračevo ponašanje odlikuje se iskazivanjem prostornovremenske simetrije prema cilju, čime se smanjuje varijabilnost sistema. Pod rizik ograničenjem, vrijeme za završetak napadačke akcije je kraće i statistički značajnije u poređenju sa drugim ograničenjima. Ovi rezultati su u skladu sa rezultatima Araujo (2006), Clemente i Mendes (2011b) i Clementea i saradnici (2011) gdje igrači koji su dobili instrukcije da rizikuju u napadu su smanjili varijabilnost akcija kako bi direktno napali gol. Na primjer, u istraživanju Clemente 
SLIKA 3

Reprezentativne toplotne mape frekvencije kretanja u prostoru.

Konzervativna
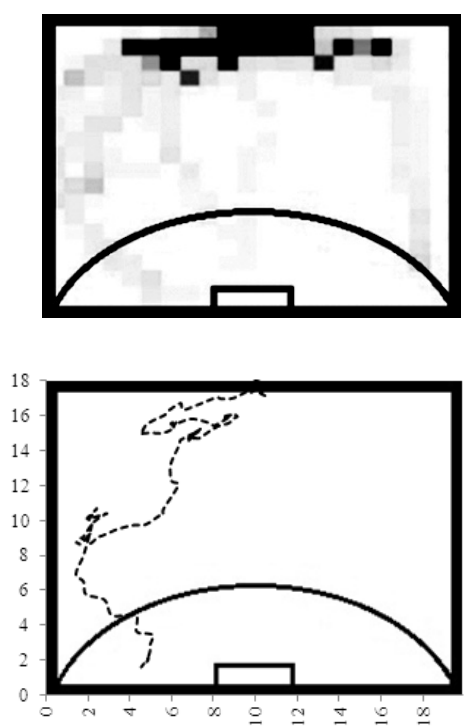

Neutralna
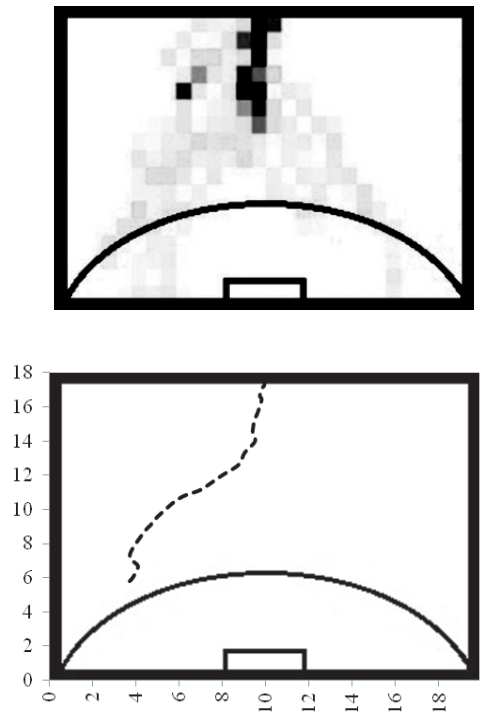

Rizik
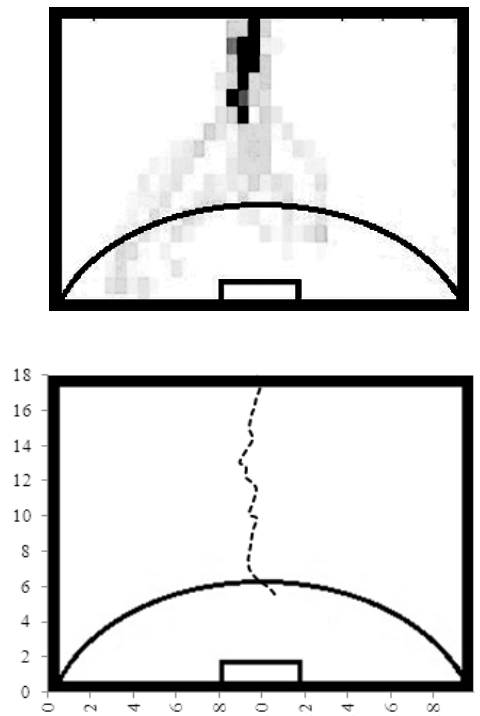

\section{SLIKA 4}

Reprezentativne toplotne mape frekvencije kretanja u prostoru.

Konzervativna
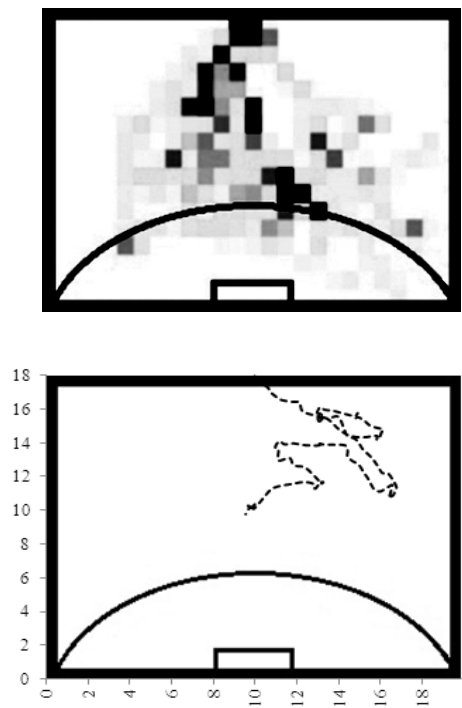

Neutralna
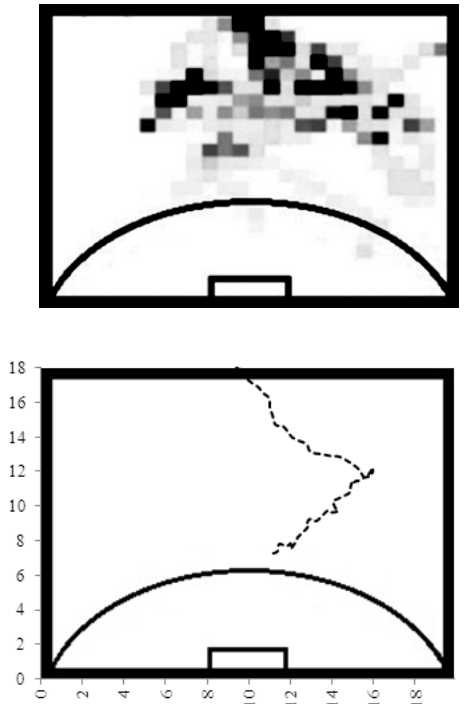

Rizik
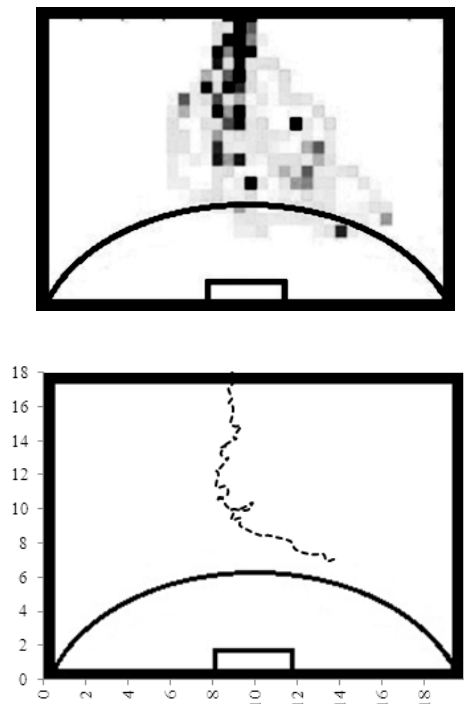

TABELA 1

Analize varijanse izmedu tri zadatka sa ograničenjima u odnosu na vrijeme napada.

\begin{tabular}{lccc}
\hline Zadaci sa ograničenjima & Rizik & Konzervativna & Neutralna \\
\hline Rizik & - & $0,01^{* *}$ & $0,01^{* *}$ \\
\hline Konzervativna & $0,01^{* *}$ & - & $0,03^{*}$ \\
\hline Neutralna & $0,01^{* *}$ & $0,03^{*}$ & - \\
\hline $\begin{array}{l}* p \leq .05 \\
* *\end{array} \leq .01$ & & & \\
\end{tabular}


i Mendesa (2011b), moguće je vidjeti da u rizik uslovima, napadač brzo prelazi protivnika i ne gubi posjed lopte kao obično. Ovi rezultati pokazuju da, u rizik zadacima sa ograničenjem, igrači pokušavaju da povećaju mogućnost da postignu gol tako što idu direktno na svog protivnika i pokušavaju da ga zaobiđu kako bi izveli direktan šut, čime se povećavaju šanse za postizanje gola. Istraživanje Clementea i Mendesa (2011b) pokazuje da je u uslovima rizika broj šuteva znatno veći nego u drugim uslovima (konzervativnom i neutralnom). Slične rezultate nalazimo i u istraživanju Clementea i saradnika (2011).

Kada su se dobili zadatak da se lopta zadrži, za razliku od rizik ograničenja, dolazilo je do bočnih akcija, čime se povećavala varijabilnost i disperzija kretanja napadača. Takođe je zaključeno da postoji statistički zanačajno produženje vremena potrebnog za završetak napadačkog pokušaja što potvrđuje rezultate istraživanja Araujoa (2006), Clementea i Mendea (2011b) i Clementea i saradnika (2011). Da se primijetiti da je napadač koristio sav prostor na raspolaganju kako bi produžio vrijeme posjeda lopte. Međutim, pokušaj da se lopta zadrži može smanjiti mogućnosti akcija napadača jer se duže vrijeme nalazi ispred protivnika. Pored toga, rezultati istraživanja Clementea i Mendesa (2011b) pokazuju da u konzervativnim uslovima, igrači se nadigravaju sa protivnikom češće nego u rizičnim kao i da više gube loptu. Ovi rezultati su u skladu sa istraživanjem Clementea i saradnika (2011), što može da značiti da napadač treba da zadrži loptu prije nego što šutne, a time je i izložen akcijama protivnika tako da je u prilici da češće gubi loptu. Osim toga, u istraživanjima Clemente i Mendese (2011b) i Clemente i saradnici (2011) pokazalo se da u konzervativnim uslovima broj šuteva je manji nego u uslovima rizika.

Ukratko, zadatak sa ograničenjima pokazao se kao bitan za prostornu distribuciju igrača i vremena potrebnog za završetak napada. Utvrđeno je da je prostorna distribucija napadača varira u zavisnosti od vrsti dobijenog zadatka. Na osnovu dobijenih podataka, za analizu vrsta kretanja sportista na terenu posebno su od koristi toplotne mape, čime analize kretanja mogu da doprinesu učenju akcija. Drugim riječima, bez upotrebe toplotnih mapa, ne bi bilo moguće otkriti vrstu aktivnosti koja je dovela do smanjene ili povećane vremena napada u različitim uslovima treninga. $U$ stvari, tradicionalna kvantitativna analiza (notacijona analiza) možda nije prikladna za identifikovanje svih karateristika određene vještine ili taktičkog ponašanja. Ipak, korištenje novih metoda, kao što su mjerenja taktike, mogu da omoguće prevazilaženje ograničenja koji su sastavni dio notacione analize. Dakle, notaciona ili kinematička analiza treba da budu dopunjene sa novim metodama kako bi se razumjela taktička dinamika ekipe (Clemente, Couceiro, Martins i Mendes, 2012b). Ova vrsta informacije je od vitalnog značaja za uvećanje znanja u igri, kvaliteta treninga i intervencije trenera, čime se poboljšavaju kolektivni nastupi ekipa ili igrača.

\section{ZAKLJUČAK}

Upustva sa ograničenjima data u vidu zadatka pokazala su da značajno utiču na akcije igrača u segmentu igre 1 na 1. U tom smislu i imajući u vidu prethodno sprovedenu analizu jasno je da su zadaci dati od strane trenera su ograničenje koje utiče na vještine igrača, čime se ukazuje na potencijal trenera da poboljšaju kvalitet podučavanja i treniranja (Clemente i Mendes, 2011b; Clemente i saradnici, 2011).

Osim toga, dobijeni podaci pokazuju da je moguće da se dokaže važnost korištenja novih metoda kinematičke analize, kao što su toplotne mape kako bi analizirali trendove i obrasce ponašanja igrača na terenu.

\section{LITERATURA}

Akritas, M. G., \& Papadatos, N. (2004). Heteroscedastioc One-Way ANOVA and Lack-of-Fit Tests. Journal of the American Statistical Association, 99(466), 368-390. doi: 10.1198/01621450 4000000412

Araújo, D. (2006). Tomada de Decisão no Desporto [Decision-making in Sport]. Cruz Quebrada, POR FMH Edições.

Araújo, D., Davids, K., Bennett, S.J., Button, C., \& Chapman, G. (2004). Emergence of sport skills under constraint. In A. M. Williams and N. J. Hodges (Eds.), Skill Acquisition in Sport: Research, Theory and Practice (pp. 409-433). London, GBR: Routledge, Taylor \& Francis.

Clemente, F., Couceiro, M., Martins, F. M. L., \& Mendes, R. (2012a). The usefulness of smallsided games on soccer training. Journal of Physical Education and Sport, 12(1), 93-102.

Clemente, F., Couceiro, M., Martins, F. M. L., \& Mendes, R. (2012b). Team's Performance on FIFA World Cup 2011: Study based on Notational Analysis. Journal of Physical Education and Sport, 12(1), 13-17.

Clemente, F., \& Mendes, R. (2011a). Aprender o jogo jogando: uma abordagem transdisciplinar [Learning the game through the playing: A multidisciplinary approach]. Revista Cientifica Exedra, $5(1), 27-36$. 
Clemente, F., \& Mendes, R. (2011b). Constrangimentos instrucionais em futebolistas sub-12 na sub-fase de jogo 1 x 1 com guarda-redes [Instructional Constraints in U-12 soccer players at the $1 \mathrm{v} 1$ sub-phase with goalkeeper]. In P. Mouroço, O. Vasconcelos, J. Barreiros, and R. Matos (Eds.), Estudos em Desenvolvimento Motor da Criança IV (pp. 146-152). Leiria, POR: ESECS/IPL.

Clemente F, Mendes, R., \& Soler, F. C. (2011). Constrangimentos instrucionais em futebolistas sub18 na sub-fase de jogo $1 \times 1$ com guarda-redes [Instructional Constraints in U-18 soccer players at the $1 \mathrm{v} 1$ sub-phase with goalkeeper]. Revista Portuguesa de Ciências do Desporto, 11, supl. 4, 45.

Davids, K., \& Araújo, D. (2005). A abordagem baseada nos constrangimentos para o treino desportivo [The Constraints-led Approach in Sport Training]. In D. Araújo (Ed.), O Contexto da Decisão - A acção táctica no desporto (pp. 35-60). Lisboa, POR: Visão e Contextos, Lda.

Davids, K., Button, C., \& Bennett, S. (2008). Dynamics of Skill Acquisition: A Constraints-Led Approach. Champaign, IL: Human Kinetics.

Duarte, R., Araújo, D., Fernandes, O., Fonseca, C., Correia, V., Gazimba, ... Lopes, J. (2010a). Capturing complex human behaviors in representative sports contexts with a single camera.

Medicina (Kaunas), 46(6), 408-414. doi: 10.2174/ 1875399X01003010016

Duarte, R., Araújo, D., Gazimba, V., Fernandes, O., Folgado, H., Marmeleira, J., \& Davids, K. (2010b). The Ecological Dynamics of 1v1 SubPhases in Association Soccer. The Open Sports Sciences Journal, 3, 16-18.

Figueira, F. M., \& Greco, P. J. (2008). Futebol: um estudo sobre a capacidade táctica no processo de ensino-aprendizagem-treinamento [Soccer: Study about the tactical knowledge in the teaching-learning-training process]. Revista Brasileira de Futebol, 1(2), 53-65.

Handford, C., Davids, K., Bennett, S, \& Button, C. (1997). Skill acquisition in sport: Some applications of an evolving practice ecology. Journal of Sport Sciences, 15(6), 621-640. doi: 10.1080/ 026404197367056; PMid: 9486439

Laureano, R. M. (2011). Teste de Hipóteses com o SPSS. O men manual de consulta rápida [Hypothesis' tests in SPSS. My manual for quick consultation]. Lisboa, POR: Edições Sílabo.

Maroco, J., \& Bispo, R. (2003). Estatística Aplicada às Ciências Sociais e Humanas [Applied Statistics at the Social and Human Sciences]. Lisboa, POR: Climepsi Editores.

Maroco, J. (2010). Análise Estatística com o PASW Statistics [Statistical Analysis with PASW Statistics]. Lisboa, POR: Edições Sílabo.

McGarry, T., Anderson, D., Wallace, S., Hughes, M., \& Franks, I. (2002). Sport competition as a dynamical self-organizing system. Journal of Sports Sciences, 20, 771-781. doi: 10.1080/026404102 320675620; PMid: 12363294

Newell, K. M. (1986). Constraints on the development of coordination. In M. G. Wade \& H. T. A. Whiting (Eds.), Motor Development in Children: Aspects of Coordination and Control (pp. 341-360). Dordrecht, NED: Martinus Nijhoff.

Passos P., Araújo, D., Davids, K., Gouveia, L., Milho, J., \& Serpa, S. (2008). Information-governing dynamics of attacker-defender interactions in youth rugby union. Journal of Sports Sciences, 16(13), 1421-1429.

Passos, P, Lopes, R., \& Milho, J. (2008). Análise de padrões de coordenação interpessoal no umcontra-um no Futebol [Pattern Analysis of the Interpersonal Coordination in Soccer 1-a-side]. Revista Portuguesa de Ciência do Desporto, 8(3), 365-376. doi: 10.1080/02640410802208986; PMid: 18923958

Pedrosa, A. C., \& Gama, S. M. A. (2004). Introducão computacional à probabilidade e estatística [Introduction Computational Probability and Statistics]. Porto, POR: Porto Editora.

Pestana, M. H., \& Gageiro, J. N. (2008). Análise de dados para as ciências sociais: $A$ complementaridade do SPSS [Data Analysis for the Social Sciences: The complamentarity of the SPSS] (5th edition). Lisboa, POR: Edições Sílabo.

Travassos, B., Araújo, D, Correia, V., \& Esteves, P. (2010). Eco-Dynamics Approach to the study of Team Sports Performance. The Open Sports Sciences Journal, 3, 56-57. doi: 10.2174/1875399 X01003010056

Vincent, W. J. (1999). Statistics in Kinesiology (2nd Edition). Champaign, IL: Human Kinetics.

Vilar, L., Castelo, J., \& Araújo, D. (2010). Pressupostos para a conceptualização do exercício de treino de futebol. Um estudo realizado com treinadores com certificado de nível IV [Assumptions for the conceptualization of soccer training exercise. study of coaches with level IV certified]. Revista Gymnasium, 1(3), 121-142. 
Primljeno: 7. juli 2011. godine Izmjene primljene: 15 . mart 2012. godine Odobreno: 2. april, 2012. godine

Korespodencija: Dr Filipe Clemente Faculdade de Ciências do Desporto e Educação Física Estádio Universitário de Coimbra, Pavilhão 3 3040-156 Coimbra Portugal

E-mail: filipe.clemente5@gmail.com Telefon: 00351239802770 Fax: 00351239802779 